\title{
Rеввавсн автіст: An analysis of perceived attributes of farm machinery and equipments by farmers in selected crops in Karnataka
}

\author{
P. Nagarjuna Reddy and Jagadeesh G. Angadi
}

Article Chronicle:

Received :

19.05.2018;

Revised :

17.06.2018;

Accepted :

01.07.2018

KeY Words :

Farm mechanization, Relative advantage, Compatibility, Complexity, Trialability
Author for correspondence :

P. Nagarjuna Reddy Department of Agricultural Extension Education, University of Agricultural Sciences, Dharwad (Karnataka) India

Email:nagarjun912@ gmail.com

See end of the article for authors' affiliations
SUMMARY : The study was aimed to reveal the farmers' perception towards different attributes of various farm machinery viz., relative advantage, compatibility, complexity, and trialability. Data were gathered from a sample of total 240 farmers through a well-structured interview schedule. Each implement was analyzed in terms of its perceived attributes by the farmers by taking the frequency and percentage for each attribute. The level of perception of different attributes for each implement by the farmers as noticed in the study needs to be analyzed in depth, so as to refine the existing implements or reorient the extension activities for effective dissemination of farm machinery.

How to cite this article : Reddy, P. Nagarjuna and Angadi, Jagadeesh G. (2018). An analysis of perceived attributes of farm machinery and equipments by farmers in selected crops in Karnataka. Agric. Update, 13(3): 303-305; DOI : 10.15740/HAS/AU/13.3/303-305. Copyright@ 2018: Hind Agri-Horticultural Society. 